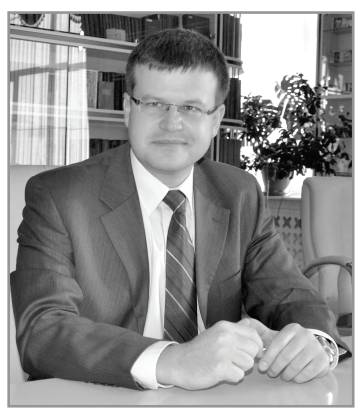

Borys Kormych*

Doctor of Law Science, Professor,

Head of Maritime \& Customs Law Department,

National University "Odessa Law Academy",

Honoured Lawyer of Ukraine

(Odessa, Ukraine)

ORCID: https://orcid.org/0000-0001-5948-5944

*Borys Kormych, Doctor of Law Science, Professor, Head of Maritime \& Customs Law Department of National University "Odessa Law Academy", Honoured Lawyer of Ukraine (Fontanskaya Doroga St., 23, Odessa, Ukraine).

\title{
THE MODERN TRENDS OF THE FOREIGN TRADE POLICY IMPLEMENTATION: IMPLICATIONS FOR CUSTOMS REGULATIONS
}

\author{
СУЧАСНІ ТЕНДЕНЦЇ̈ РЕАЛІЗАЦЇ̈ \\ ЗОВНІШНЬОЕКОНОМІЧНОЇ ПОЛІТИКИ: \\ НАСЛІДКИ ДЛЯ МИТНИХ ПРАВИЛ
}

\begin{abstract}
The paper analyses basic transformation tendencies in the international trade policy standards generated within frameworks of global and regional institution and their influence upon customs and border formalities. The transformation of standards is also supplemented with crucial changes in a rule-making process, that conventionally has been an exclusive competence of national states. That rule-making changes are characterised by transferring the significant amount of competence from the national states to the global and supranational level, as well as by introduction new types of rule-making actors (both public and private) and new types of law sources. This urges us to apply to the analyses the concepts of global governance, transnational law and global administrative law, which focus on the above-mentioned transformations in the field. Customs authorities now are experiencing the transition of their initial mission from merely revenue collectors to actors responsible for extensive range of tasks, including safety and security issues, trade facilitation, joint border management, etc. All these tasks should
\end{abstract}


be performed at the high level of harmonisation, unification and standardization with recognised international and regional rules and regulations. Due to the specifics of the new mission of customs authorities, the paper primary focuses on two relatively new tasks of security and trade facilitation. And also paper discuses two basic modern instruments to implement such tasks - the operation of Single Window for international trade and the application of good governance principles to customs routine operations. The essential point is that two instruments are not focused merely on improving the way customs and border formalities are performed by authorities, but also starve the whole system of border management into comprehensive reform of both interagency and intra-agency procedures and operations. The Single Window facility provides such reform through joint application of information technology based on internationally approved standards. The WTO rules for good governance for application of customs legislation in fact demands from member states to share common values and principles, originally emerged within legal systems of western developed countries.

The key words: trade policy, customs regulations, customs formalities, trade facilitation, security, global supply chain, Single Window, good governance, WTO, WCO, UN/SEFACT Introduction.

\section{Introduction}

The extensive development and universal recognition of international standards that bind states on the issues of ways and means of foreign trade policy implementation may be considered as the key factor that changes the image and the role of customs and other border authorities, as well as respective customs laws and regulations. International instruments provide a wide range of rules and standards, which focus on tariff and non-tariff trade policy instruments. But the same instruments also set procedural demands referring to the application of customs regulations, internal decision-making process of public authorities involved, requirements for data formats and use of information technologies, etc. Thus, the paper urges to review the influence of underlying trends of trade policy upon customs regulations and its application procedure.

\section{The Diversity of Standards for The Foreign Trade Policy Implementation: Globalization, Regionalization and Privatization}

The modern ways and means of foreign trade policy application are bind with the system of global rules and principles that emerged in the second half of the 20th century and continue to evolve through international cooperation in the frameworks of WTO multilateral trading system. These principles are grounded on the ideas of neoliberalism that were common for the early years of GATT-47, which combined the free trade ideals 
with the recognition of administrative regulation's necessity and respect for public needs. The neoliberal vision "is particularly dominant in the regimes of WTO Law and international investment law..." and due to "the institutional ties between the WTO and some of the global standardization regimes [through the TBT and SPS Agreements], this ethos also influences the norm-production process in their respective spheres" (Barak-Erez \& Perez, 2013, p. 462). In fact, the global rule-making process in the field is not limited to the WTO itself. We may allocate two other key centers for the development of trade policy implementation standards interacting with the WTO on various matters of customs and border formalities. The World Customs Organization (WCO) and the UN in guises of its agencies (UNCTAD, UN EEC, UN/SEFACT, etc.) represent them.

The legal regimes emerged in the frameworks of above-mentioned institutions, have a common feature that consist in progressively rising level of autonomy. Due to that autonomy national states become more and more bind not just with the rules of proper international agreements, but also with the rules created by international organizations itself in the forms of WTO committees decisions, DSB reports, WMO pillars of standards, etc.

These trends of foreign trade policy have been extensively discussed in a number of scholarships. They are starting with a comprehensive global governance concept, which has been actively developing since the 1970s and ending with more specific approaches such as transnational law (since late 1950s) or global administrative law (since 2000th).

We can assume that the basics of global governance concept, as they were originally interpreted by I. Wallerstane, were originally linked to foreign trade policy and border formalities issues. Such links emerged due to needs of global economy with its "commodity chains" (the "Global Value Chains" - GVC in a modern vision) that have to "cross state boundaries at some point, and many (even most) will cross them at many points" (Wallerstane, 1984, p. 3). Thus, the global economy is developing enormous pressure on a modern state, requiring its consistency with generally accepted rules to ensure the best treatment of the above-mentioned "commodity chains", which is possible only through subordination to rather an autonomous global rule making institutions. Such subordination is constantly expanding because the states "are created institutions, and are constantly changing - in forms, in strength, in boundaries - through the interplay of the interstate system. Just as the world-economy has expanded over time, its political expression - the interstate system - has expanded" 
(Wallerstane, 1984, p. 4). This economic demands justify the fact that organizations like WTO "assisting in governance of financial and production structures... are notable because their rule-creating and rule-supervisory decisions have important immediate consequences for states and people around the world" (O'Brien, Goetz, Scholte, Williams, 2000, p. 11).

The trends for dispersal authority across state and beyond-state levels show that the focus is essentially shifting at the regional level, which is resulted by the tendency of the development of regional economic integration in the forms of customs unions and free trade areas. For example, according to the WTO data, merely 19 regional trade agreements (RTA) have been registered before 1990, then in 2000 their number has increased to 79 , finally the total of 288 RTA are registered up to 2018 . The absolute leader as for the number of RTA concluded is the European Union, which has 42 existing RTA and also it has informed the WTO of the intention to sign another 13 similar agreements (Regional Trade Agreements Information System).

The important point is that the effects of RTA conclusion are not limited merely to elimination of tariff and non-tariff barriers. For the lesser extends for free trade areas and greater one for customs unions, their creation typically involves deepening interaction between customs administrations, harmonisation of customs and border procedures, standardization of requirements for information exchange, implementation of elements of joint border management, etc.

With that respect, the Annex XV to Chapter 5 of the Association Agreement between Ukraine and the EU includes a comprehensive range of requirements for the approximation of customs legislation to the acquis communautaire. Those requirements lead Ukraine into the area of Europeanization of customs legislation, which covers not only the EU member states but also the partner countries. This, in particular, is caused by the EU common trade policy interconnections with the principles and objectives of the EU external action, stipulated by Art. 21 and 22 of the EU Treaty. In particular, Art. Article 21 (2) of the EU Treaty rises the issue of concluding trade agreements much above solely economic considerations, linking them with requirements to ensure the values, fundamental interests, security and integrity of the EU, support for democracy and the rule of law, etc. The tools to achieve the EU external objectives typically include concepts of "normative power" which covers propaganda of EU norms and principles beyond its borders; and "hegemonic power" which 
relies on export of norms and values to the neighboring countries (Blaese, 2013, p. 15-16).

In addition, the important trend is not only the transfer of a substantial part of the regulation of trade and customs policy to the international level, but also the "privatization" of certain elements of the process of laying down rules for such regulation. Such privatization refers to the process by which international non-governmental organizations develop and establish standards that turn into global rules recognized not only by the private sector but also by the states. Currently, experts identify at least three such organizations, which standards have a determining influence on international trade and the States' policy to regulate the latter.

The list of that organizations includes: the International Accounting Standards Board (IASB), which rules are applied by more than 100 countries; the International Organization for Standardization (ISO) and the International Electrotechnical Commission (IEC). The latter two “...jointly account for 85 percent of all international standards for the design or performance of manufactured goods. Their product standards determine market access, consumer and workplace safety, quality assurance, and competitiveness" (Büthe \& Mattli, 2011). Moreover, private-public partnership to form the particular measures for customs policy implementation is also encouraged at the national level, which is clearly articulated in recommendations and other instruments of WCO, UNECE, etc.

In closing, the other modern source of the formation and dissemination of trade policy implementation standards emerges from the horizontal cooperation between national public administration actors that are involved in the implementation of customs and border formalities (primary, between customs and border services, maritime administrations, etc.). Such cooperation is one of the channels for sharing experience and best practices, making joint decisions and coordinating joint actions in the areas of border management and the organization of the movement of goods and vehicles through adjacent frontier checkpoints. In fact, it may be viewed as the formation of "transnational networks or other informal co-operative arrangements of domestic regulatory agencies or official" that act in accordance with multilateral or bilateral international treaties (Kingsbury \& Donaldson, 2015).

Thus, we face significant diversity of "gravity centers" that form modern foreign trade policy implementation standards. Such diversity, in practice, allows national states to simultaneously grant the compliance with 
general principles of harmonization, unification and standardization of customs and border formalities, and to take into account the regional specificity, the needs of individual states and private-sector actors.

\section{The Transformation of the Role of Customs: Security}

Among the modern trends of the trade policy implementation, we should highlight the significant transformation of the role of customs, which traditionally, for many centuries, has been considered as the fiscal subject that charges customs duties and other taxes on import or export. For the recent decades the views on the functions of customs have considerably expanded "so that, in addition to revenue collection, it became responsible for ensuring the legitimacy, safety, and security of goods" and at the present stage, "customs administrations worldwide, has been asked to take on the role of trade facilitator" (Peterson, 2017, p. 2). Therefore, the activities of modern customs are characterized by three primary functions: taxation, security and trade facilitation.

For example, the Art. 3 of Union Customs Code defines the mission of EU member-states' customs authorities to put in place measures aimed, in particular, at the following:

(a) Protecting the financial interests of the Union and its Member States;

(b) Protecting the Union from unfair and illegal trade while supporting legitimate business activity;

(c) Ensuring the security and safety of the Union and its residents, and the protection of the environment, where appropriate in close cooperation with other authorities; and

(d) Maintaining a proper balance between customs controls and facilitation of legitimate trade.

The terrorist attacks in the United States on September 11, 2001, has become the factor that prompted a significant strengthening of the security component in the operations of the modern customs authorities, after which securityoriented control measures for supply chains have been widely implemented for the aims of preventing risk identification. Those measures are based on the desire of the customs authorities to "make effective use of finite enforcement resources, to improve controls at the border, to ensure that wealth-generating trade continues while extending controls up and down the supply chain" (Grainger, 2007, p. 17). Currently, we may state that the importance of border security issues, which shall be granted by customs authorities, is constantly increasing, because conventional threats of terrorism and organized crime 
have been accompanied with threats associated with hybrid operations of particular states. But exactly the events of 9/11 led to the establishment of new protocols for tracking and screening cargo both in the United States and in foreign countries. These protocols have been incorporated into WCO frameworks of standards and in country-specific programs such as the Container Security Initiative (CSI) and the Customs-Trade Partnership Against Terrorism (C-TPAT) (Peterson, 2008).

The most complete guidelines for customs security functions implementation is provided in the WCO SAFE Framework of Standards to Secure and Facilitate Global Trade (SAFE) which have already received five editions in 2005, 2007, 2010, 2012 and 2018. These standards are focused on solving the dual task of trade facilitation and cargo security, as well as on ensuring proper balance between those two issues. Customs authorities are considered to remain the key actor for achieving the goals since they are included in all three pillars of that standards - "Customs-toCustoms", "Customs-to-Business" and "Customs-to-Other Government and Inter-Government Agencies".

All three pillars are aimed to implement four basic concepts of the SAFE framework: 1) to harmonize the advance electronic cargo information requirements on inbound, outbound and transit shipments; 2) to employ a consistent risk management approach to address security threats; 3 ) to perform an outbound inspection of high-risk cargo and transport conveyances on request of receiving nations; 4) to provide benefits to businesses that meet minimal supply chain security standards and best practices.

Typically, the transformation of the role of customs is accompanied by appropriate institutional changes. Moreover, it is widely argued that "a general indication of a government's view of the role of their customs authority can often be gleaned from the way in which administrative responsibilities are structured... where the collection of revenue is the focus, customs administration is generally part of The Treasury or Finance portfolio. Similarly, those administrations that appear to play a role in protecting the border are likely to be aligned with other agencies that focus on border management" (Widdowson, 2007, p. 31). The examples of such interdependence between customs institutional framework and its functions are the reforms in the US, where the Customs Service has been merged into a joint Customs and Border Protection and in Canada, where in a similar manner few government agencies were replaced with the Canada Border Services Agency. 


\section{The Transformation of the Role of Customs:}

Trade Facilitation

The trade facilitation objectives were introduced into routine of customs authorities basically because of the successful implementation of the trade liberalization policy provided by protocols of concessions within the WTO frameworks. Due to 2017 WTO tariff statistics the European Union has $100 \%$ of Customs Tariff HS subheadings with WTO bound rates, 29.2\% duty-free HS subheadings and the average rate of import duty of $5 \%$; the similar indicators for the USA are $99.9 \%$ bound HS subheadings, $46.5 \%$ duty-free HS subheadings and the average duty of 3.4\%; Canada and Japan have in their tariffs $99.7 \%$ bound, 39.1 and $53 \%$ duty-free HS subheadings and average duties of $6.5 \%$ and $4.5 \%$ respectively (World Tariff Profiles, 2017).

The significant reduction of tariff and non-tariff barriers, that is common for developed countries, has two substantial consequences for shifting the emphasis for the international trade policy implementation. First, "since tariff barriers come down, the customs revenue-raising function has diminished in relative importance, especially for developed countries" and what is the most important "customs regulations or procedures are no longer tied closely to the revenue target" (Zang, 2002, p. 89). Thus, the possibility of simplifying customs procedures with an moderate level of risk for national revenue has opened up for a significant number of states. Second, the reduction of customs tariffs has caused the situation where the amount of import duties has become commensurate or even lower than trade transaction costs (TTC) with regards to compliance with customs and border formalities, since the latter are estimated on various data ranging from $1.5 \%$ to $15 \%$ of the transaction value (Milner, Morrissey \& Zgovu, 2008). Respectively, trade transaction costs has started to be considered as the main trade barrier in the conditions of liberalized market access.

Finally, two other factors that lead to erecting trade facilitation issues are peculiarities of industrial development in the modern global world. The first one is arising of the Global Value Chains (GVC) that have become primary indicators of such changes, and the key characteristics of which are: the increasing fragmentation of production in different countries, so that global value chains link geographically dispersed activities in a single industry; and the specialization of countries in the tasks and business functions, rather than specific products (De Backer, Miroudot, 2014, p. 4). Today, up to half of the total imports and exports of developed countries 
comprise of "intermediate goods", which are components of the corresponding GVCs. Next, there is expansion of production processes based on the principles of Just-In-Time (JIT) and of e-commerce shipments, which increased the requirements for the speed release of goods by customs. Accordingly, the cost of customs borders for business has increased significantly, and "Trade policy instruments such as import tariffs, rules of origin, anti-dumping, etc. may therefore directly hurt the competitiveness of domestic industries. Instead of "beggar thy neighbor" policies, protectionist policies may become "beggar itself" policies" (Mapping Global Value Chains, 2012, p. 4).

The contemporary understanding of the "trade facilitation" concept is based on the Recommendation No. 4 of UN / CEFACT "National Trade Facilitation Bodies". According to its provisions "facilitation covers formalities, procedures, documents and operations related to international trade transactions. Its goals are simplification, harmonization and standardization, so that transactions become easier, faster and more economical than before."(Par. 14). Thus, one may identify three basic elements of the trade facilitation, which include:

1) Simplification, that is the process of eliminating all unnecessary elements and duplications in formalities, processes and procedures (Par. 15);

2) Harmonization, which focuses on the alignment of national formalities, procedures, operations and documents with international conventions, standards and practices (Par. 17);

3) Standardization, that in regards of trade facilitation means the process of developing internationally agreed formats for practices and procedures, documents and information (Para. 19).

It is used to say that trade facilitation issues for the first time at the international level were articulated in the WCO International Convention on the Simplification and Harmonization of Customs Procedures as reviewed on June 26, 1999. This convention contains a number of key provisions that define the image of modern customs: the use of information and communication technologies for customs clearance, the introduction of risk management tools, coordination between border agencies of neighboring countries, and so on.

But definitely, the basic international instrument in the field is the 2013 Trade Facilitation Agreement (TFA), which was signed after more than 10 years of the Doha Round negotiations. At the same time the TFA, just like many other WTO trade agreements, is directly based on the norms of 
several initial articles of the GATT (Articles V, VIII and X) clarifying and improving their provisions and contains only one completely new norm on customs cooperation (Table 1).

Table 1

Trade Facilitation Measures "Clarify and Improve" Aspects of the GATT (McDougall, 2017)

\begin{tabular}{|c|l|}
\hline \multicolumn{2}{|c|}{ GATT Article X: Publication and Administration of Trade Regulations } \\
\hline TFA Art. 1. & Publication and Availability of Information \\
\hline TFA Art. 2. & $\begin{array}{l}\text { Opportunity to Comment, Information before Entry into Force and } \\
\text { Consultation }\end{array}$ \\
\hline TFA Art. 3. & Advance Rulings \\
\hline TFA Art. 4. & Procedures for Appeal or Review \\
\hline TFA Art. 5. & $\begin{array}{l}\text { Other Measures to Enhance Impartiality, Non-Discrimination and } \\
\text { Transparency }\end{array}$ \\
\hline \multicolumn{2}{|c|}{ Fees and Formalities Connected with Importation and Exportation } \\
\hline TFA Art. 6. & $\begin{array}{l}\text { Disciplines on Fees and Charges Imposed on or in Connection with } \\
\text { Importation and Exportation and Penalties }\end{array}$ \\
\hline TFA Art. 7. & Release and Clearance of Goods \\
\hline TFA Art. 8. & Border Agency Cooperation \\
\hline TFA Art. 9. & Movement of Goods Intended for Import under Customs Control \\
\hline TFA Art. 10. & Formalities Connected with Importation, Exportation and Transit \\
\hline \multicolumn{2}{|c|}{ GATT Article V: Freedom of Transit } \\
\hline TFA Art. 11. & Freedom of Transit \\
\hline \multicolumn{2}{|c|}{ New Obligation } \\
\hline TFA Art. 12. & Customs Cooperation \\
\hline
\end{tabular}

\section{The Single Window for International Trade: \\ Border Management Integration}

The principal change in the technical aspects of the implementation of trade facilitation measures has been caused by the introduction of solutions based on information and communication technologies (ICTs), the most significant form of which doubtlessly is the Single Window. Moreover, the Single Window is considered not only as a "national electronic information exchange with a focus on legislation, procedures, and information and communications technology" (McLinden, Fanta, Widdowson \& Doyle, 2011, p. $125)$, but as a tool that is to change the very philosophy of foreign 
trade administration so that separate government agencies responsible for customs and border formalities, licensing and issuing permits shall co-ordinate their activities through the use of common ICT and therefore provide better services for citizens and business. Furthermore, such association of frontier formalities actors may involve non-state actors responsible for transport and logistics, financial services for foreign trade, etc.

As for the regulation framework, the operation of the Single Window is based on the provisions of the WCO International Convention on the Simplification and Harmonization of Customs Procedures and the WTO Agreement on Trade Facilitation.

Peculiarly, the International Convention on the Simplification and Harmonization of Customs Procedures contains three standards relating to: the automated Customs clearance processes (3.11), the application of information technology to support Customs operations (7.1) and the usage of relevant internationally accepted standards when introducing computer applications (7.2).

The WTO Trade Facilitation Agreement contains Art. 10 (4.1) that encourages member-states "to establish or maintain a single window, enabling traders to submit documentation and/or data requirements for importation, exportation, or transit of goods through a single entry point to the participating authorities or agencies. After the examination by the participating authorities or agencies of the documentation or data, the results shall be notified to the applicants through the single window in a timely manner". Besides, the Art. 10 (4.2) in the clear language prohibits government agencies from repeatedly requesting the same documentation or data that has been already lodged via Single Window facility.

Indicatively, the significant role in regulation of national Single Window facilities is played by the "soft law" in forms of recommendations, guidelines and "best practices", which are actively issued by international institutions, such as WMO and The United Nations Centre for Trade Facilitation and Electronic Business (UN/CEFACT).

For example, UN CEFACT issued a series of recommendations for the establishment and maintenance of the Single Window facilities:

- Recommendation No. 33 "Recommendation and Recommendations for Creating a Single Window to Enhance Effective Information Exchange between Trade and Government", which suggested possible Single Window concepts and relevant Government action. 
- Recommendation No. 34 "Simplification and standardization of data for international trade", which deals with the practical aspects of the Single Window application.

- Recommendation No. 35. "Setting the legal framework for international trade in a single window" that focuses at the legal aspects of the Single Window.

But the most important point to understand the changes in customs techniques and methods of public administration that are offered through the Single Window is WCO position, according to which "Single Window Environment is, in fact, an "intelligent" facility that allows parties involved in trade and transport to lodge standardized information, mainly electronic, with a single entry point to meet all import, export and transit related regulatory requirements" (WCO Compendium, 2014).

To be specific, the reference to the "intelligence" of this facility encourages considering the Single Window not only as a conventional webportal, but as a specific communication channel that enables all involved government agencies to provide joint services to foreign trade actors, and the latter, in turn, to receive integrated vision of all aspects of respective transactions.

The reference to "Single Window Environment" should show that the shared application of ICT creates a specific ecosystem of recognized for the information exchange and business processes, accompanied with the integration of both state and non-state actors involved in foreign trade. In particular, this concerns the harmonization of information submission, the exchange of information between government agencies, the adoption of administrative acts, etc.

\section{Customs \& Border Formalities: The Issue of Good Governance}

The essential condition for the appropriate and effective trade policy implementation by customs authorities is the compliance of the national public administration in the field with the basic principles on which the relevant standards were formed within frameworks of international institutions.

In order to acknowledge the importance of this task, one should consider certain aspects of the transnational law concept, which may largely explain the modern legal regulation of international trade. It is the issue of the mechanism of forming its norms, which Harold Koh has described using a computer terminology as "the law that is "uploaded then down- 
loaded" for example a rule that originates in domestic legal system... which than become a part of international law... and from there become internalized into nearly every legal system in the world" (Koh, 2006). Put differently, the point is that most of the WTO rules has been emerged from the national legal systems of developed states and are based of the principles inherent in these systems of law.

A good example of such processes is the of Art. X GATT, which is considered to be a cornerstone of the national level application of customs tariff and other supplementary regulations. It is also argued that the Art. X is the provision where "the oldest good governance and transparency obligation of the WTO is contained" (Ala'I, 2008). In other words, the Art. X GATT encourages the member states to apply the Western approaches to their national governance process and to share appropriate values and principles. "This provision basically requires the rule of law in trade regulation: transparency of trade measures, uniform and impartial administration, and review. Interestingly, it was originally proposed by the US Government and drew clear inspiration from the 1946 US Administrative Procedure Act" (Stewart \& Badin, 2011).

Thus, we have a clear situation when a specific set of national rules and principles of administrative procedures, that is common for Western democracies, has been accepted as a standard at the international level. Such acceptance has become possible, particularly, due to economic and political influence, as well as a high reputation of public administration systems of developed countries (in this case - USA), which have generated respective rules and principles. "As a result, to be accepted as a new WTO member, developing and transition state members must accept and internalize these unfamiliar policies in order to meet the demands of global integration and economic promotion. In imposing such requirements, the WTO has clearly become a mechanism by which international norms originating in Western industrialized countries have been imposed; these are then adopted by weaker members with varying degrees of enthusiasm" (Van Tran, 2016).

Therefore, effective application of the WTO rules can be carried out merely if being subject to the general principles of good governance inherent in Western countries. Moreover, Art. 10 (3) The GATT articulates that "Each contracting party shall administer in a uniform, impartial and reasonable manner all its laws, regulations, decisions and rulings...", that actually shows that particular standards are applied not solely to the 
administrative procedures itself, but also to the way national officials perform their judgments and discretion in decision-making processes.

Furthermore, within the WTO Dispute Settlement frameworks, the Panels developed their own evaluation of reasonability. For example in the case Dominican Republic - Import and Sale of Cigarettes the Panel adopted literal interpretation of the term and concluded that "the ordinary meaning of the word "reasonable", refers to notions such as "in accordance with reason, not irrational or absurd", "proportionate", "having sound judgement", "sensible", "not asking for too much", "within the limits of reason, not greatly less or more than might be thought likely or appropriate", "articulate" (Dominican Republic - Import and Sale of Cigarettes, 2004, para. 7.385).

Hence the issue of reasonability covers the application of such categories as "logic" and "common sense" ether to actual acts of public authorities or to the explanation of such acts provided. In the case US - COOL the Panel states that in its view "whether an act of administration can be considered reasonable within the meaning of Article X:3(a) entails a consideration of factual circumstances specific to each case" and that evaluation of reasonability "requiring the examination of the features of the administrative act at issue in the light of its objective, cause or the rationale behind it" (US - COOL, 2011, para. 7.851).

Currently the WTO demands of good governance achieve broader interpretation far overwhelming merely needs of dispute settlement. For example, the WTO promotion of good governance is proposed to be placed "within the larger framework of the ongoing global anti-corruption movement" (Ala'I, 2008), or it is stated that the newest Trade Facilitation Agreement, that clarifies rulings of Art. X GATT, "commits WTO members to implement common sense customs reforms" (The WTO Trade Facilitation Agreement, 2017, p. 20).

\section{Conclusion}

The modern standards for international trade policy implementation have emerged from contemporary demands of global economy and can be examined through number of legal and administration theories including global governance, transnational law, global administrative law, etc. These standards are characterized by such peculiarities as a relative autonomy of the legal order, the crucial role of international institutions in a rulemaking process, growing importance of RTA rules and involving of nonstate rule making actors. 
Economical and political changes lead to the significant transformation of the essential role of customs authorities from revenue collection to security and trade facilitation objectives. But this transformation is tightly connected with the taxation system structure that is common for developed states where customs covers merely from $4 \%$ to $10 \%$ of combined revenue and less attention to collection of customs duties and charges does not cause extra risks for income of state budget. In developing and transiting states, with the customs revenue sharing up to $40 \%$ all budget revenues, customs authorities may experience excess pressure fromboth state's government and business community towards performing the fiscal function what may result in extra corruption risks in the field.

The large-scale application of ICT for customs and border formalities has used to be considered as a key tool for trade facilitation. The most advanced ICT trade facilitation facility is a Single Window for international trade. A Single Window should not be viewed as a simple single portal for lodging data that saves time and transaction operational costs. Its functions are much more wider and includes transformations of the ways and means of cooperation between public authorities that perform border management functions.

The fact that basic international standards for national application of customs legislation have originated in legal systems of developed states causes the situation that simple mechanical transfer of procedural norms established by international or EU Law does not resolve the issue of proper quality of administration in the states that do not share the values and principle that are common for western democracies. Thus the proper implementation of modern principles of security and trade facilitation goes far beyond the scope of the organization of the customs service and covers almost the entire system of public authorities in the country.

\section{REFERENCES}

6 U.S. Code $\S 211$. Establishment of U.S. Customs and Border Protection; Commissioner, Deputy Commissioner, and operational offices. $<\mathrm{http}: / /$ uscode.house.gov/ $>$

Ala'I. P. (2008). The WTO and the Anti-Corruption Movement. Loyola University Chicago International Law Review, 6, 1, 259-278.

Annex to the Protocol Amending the Marrakesh Agreement Establishing the World Trade Organization Agreement on Trade Facilitation / WT/L/940. 28 November 2014. $<$ https://www.wto.org/english/tratop_e/tradfa_e/tradfa_e.htm> 
Barak-Erez, D., Perez, O. (2013). Whose Administrative Law is it Anyway? How Global Norms Reshape the Administrative State. Cornell International Law Journal, 46, 456-497.

Blaese, J-D. (2013). International Institutions and the Power of the EU: How Has it Been Affected by the Financial Crisis? Hamburg: Anchor Academic Publishing.

Büthe, T., Mattli, W. (2011). The Privatization of Regulation in the World Economy. The Regulatory Review. <https://www.theregreview.org/2011/05/24/ the-privatization-of-regulation-in-the-world-economy $>$

Canada Border Services Agency. <https://www.cbsa-asfc.gc.ca/menu-eng.html>

Data Simplification and Standardization for International Trade. Recommendation No. 34. (2010) UN/CEFACT. ECE/TRADE/400.

De Backer, K., Miroudot, S. (2014). Mapping Global Value Chains. Working Paper Series No. 1677. European Central Bank. <https://www.ecb.europa.eu/pub/pdf/scpwps/ ecbwp1677.pdf>

DOMINICAN REPUBLIC - MEASURES AFFECTING THE IMPORTATION AND INTERNAL SALE OF CIGARETTES. WORLD TRADE ORGANIZATION. (2004) Report of the Panel. WT/DS302/R.

Establishing a legal framework for international trade Single Window. Recommendation No.35. (2011) UN/CEFACT. ECE/TRADE/401.

Grainger, A. (2007). Supply chain security: adding to a complex operational and institutional environment. World Customs Journal, 1, 2, 17-29.

How to build A Single Window Environment. WCO Compendium. (2014) World Customs Organization. Vol. 1.

INTERNATIONAL CONVENTION ON THE SIMPLIFICATION AND HARMONIZATION OF CUSTOMS PROCEDURES (as amended) 2008 (Customs Co-operation Council). Brussels: World Customs Organisation. <http://www.wcoomd.org/-/media/wco/public/global/pdf/topics/facilitation/instruments-and-tools/conventions/kyoto-convention/ revised-kyoto-convention/body_gen-annex-and-specific-annexes.pdf?la=en>

Kingsbury, B., Donaldson, M. (2015). Global Administrative Law. In Max Planck Encyclopedia of Public International Law. Oxford Public International Law. Oxford University Press. <http://opil.ouplaw.com>

Koh, H. (2006). Why Transnational Law Matters. Yale Faculty Scholarship Series. Paper 1793. <http://digitalcommons.law.yale.edu/fss_papers/1793>

Mapping Global Value Chains. (2012) Organization for Economic Co-operation and Development. TAD/TC/WP/RD(2012)9. < Chttps://www.oecd.org/dac/aft/Mapping GlobalValueChains_web_usb.pdf $>$

McDougall, R. (2017). Evaluating the Implementation Obligations of the Trade Facilitation Agreement in the Context of Existing Multilateral Trade Rules. Geneva: International Centre for Trade and Sustainable Development (ICTSD). < https://www.ictsd.org/sites/ default/files/research/evaluating_the_implemenation_of_the_tfa.pdf $>$ 
McLinden, G., Fanta, E., Widdowson, D., Doyle, T. (Eds.) (2011). Border Management Modernization. Washington DC. The World Bank.

Milner, C., Morrissey, O., Zgovu, E. (2008). Trade Facilitation in Developing Countries. Research Paper No. 08/05. <https://www.researchgate.net/ publication/5199934_Trade_Facilitation_in_Developing_Countries $>$

Mitchell, A. (2008). Legal Principles in WTO Disputes. Cambridge University Press.

National Trade Facilitation Bodies. Recommendation No. 4, second edition. (2001) UN/CEFACT. ECE/TRADE/242. <https://www.unece.org/fileadmin/DAM/cefact/recommendations/rec04/rec04_ecetrd242e.pdf $>$

O’Brien, R., Goetz, A., Scholte, J., Williams, M. (2000). Contesting Global Governance: Multilateral Economic Institutions and Global Social Movements. Cambridge: Cambridge University Press.

Peterson, J. (2017). An Overview of Customs Reforms to Facilitate Trade. Journal of International Commerce and Economics. August, 1-30.

Peterson, J., Treat, A. (2008). The Post-9/11 Global Framework for Cargo Security. Journal of International Commerce and Economics. March. <https://www.usitc.gov/publications/332/journals/cargo_security.pdf $>$

Recommendation and Guidelines on Establishing a Single Window to Enhance the Efficient Exchange of Information between Trade and Government, No. 33 (2005). UN/CEFACT. $\mathrm{ECE} / \mathrm{TRADE} / 352$.

Regional Trade Agreements Information System 2017 (World Trade Organization). $<$ http://rtais.wto.org/UI/PublicMaintainRTAHome.aspx>

Regulation No. 952/2013 Of The European Parliament And Of The Council of 9 October 2013 laying down the Union Customs Code (EU). Official Journal of the European Union. 10.10.2013. L 269.

SAFE Framework of Standards to Secure and Facilitate Global Trade. (2018) World Customs Organization. <http://www.wcoomd.org/-/media/wco/public/global/pdf/topics/ facilitation/instruments-and-tools/tools/safe-package/safe-framework-of-standards. pdf?la $=$ en>

Stewart, R., Badin, M. (2011). The World Trade Organization: Multiple dimensions of Global Administrative Law. International Journal of Constitutional Law, 9, 3-4, 556-586. $<$ https://doi.org/10.1093/icon/mor051>

The WTO Trade Facilitation Agreement. (2017) Across Borders. Winter, 20-21. <http:// www.ftalliance.com.au/data/accrossborder_attachments/24_across\%20borders $\% 20-\% 20$ winter\%202017.pdf>

UNITED STATES - CERTAIN COUNTRY OF ORIGIN LABELLING (COOL) REQUIREMENTS. World Trade Organization. (2011). Reports of the Panel. WT/DS384/R. WT/DS386/R. 
Van Tran, L. (2016). The power of transparency norms in the WTO legal framework: Impacts beyond the trade context. International Review of Law, 3. < http://dx.doi.org/ 10.5339/irl.2016.iit.2>

Wallerstein, I. (1984). The Politics of the World-Economy: The States, the Movements and the Civilizations. Cambridge: Cambridge University Press.

Widdowson, D. (2007). The Changing Role of Customs: Evolution or Revolution? World Customs Journal, 1, 1, 30-37.

World Tariff Profiles 2017 (World Trade Organization). <https:/www.wto.org/english/ res_e/booksp_e/tariff_profiles17_e.pdf>

Zhang, A. (2002). Electronic technology and simplification of customs regulations and procedures in air cargo trade. Journal of Air Transportation, 7, 2, 87-102..

\section{АНОТАЦІЯ}

Кормич Б. А. Сучасні тенденцї̈ реалізації зовнішньоекономічної політики: наслікки для митних правил. - Стаття.

У роботі аналізуються основні тенденції трансформації стандартів міжнародної торговельної політики, сформованих у рамках глобальних та регіональних інституцій, та їх вплив на митні та прикордонні формальності. Трансформація стандартів також доповнюється важливими змінами у процесі нормотворення, що традиційно було винятковою компетенцією національних держав. Відповідні зміни характеризуються переходом значного обсягу компетенції від національних держав на глобальний і наднаціональний рівень, а також появою нових типів акторів, що здійснюють нормотворчість (як державних, так і приватних) та нових типів джерел права. Це спонукає нас звернутися до аналізу концепцій глобального управління, транснаціонального права та глобального адміністративного права, які сфокусовані на вищезгаданих трансформаціях у цій галузі. Митні органи зараз переживають перехід від традиційної місії лише збирачів податків до суб'єктів, відповідальних за широкий спектр завдань, включаючи питання безпеки та захисту, сприяння торгівлі, спільного управління кордонами тощо. Всі ці завдання повинні виконуватися на високому рівні гармонізації, уніфікації та стандартизації з визнаними міжнародними та регіональними нормами та правилами. 3 огляду на специфіку нової місії митних органів, основна увага приділяється їх двом відносно новим завданням: забезпечення безпеки та спрощення процедур торгівлі. Відзначено також основні сучасні інструменти для реалізації таких завдань: функціонування “єдиних вікон” для міжнародної торгівлі та застосування принципів належного урядування до митних операцій.

Ключові слюва: торговельна політика, митні правила, митні формальності, сприяння торгівлі, безпека, глобальний ланцюжок постачання, “єдине вікно”, належне урядування, СОТ, ВМО, СЕФАКТ ООН. 


\section{АННОТАЦИЯ}

Кормич Б. А. Современные тенденции реализации внешнеэкономической политики: последствия для таможенных правил. - Статья.

В работе анализируются основные тенденции трансформации стандартов международной торговой политики, сформированных в рамках глобальных и региональных институтов, и их влияние на таможенные и пограничные формальности. Трансформация стандартов также дополняется важными изменениями в процессе нормотворчества, что традиционно было исключительной компетенцией национальных государств. Соответствующие изменения характеризуются переходом значительного объема компетенции от национальных государств на глобальный и надгосударственный уровни, а также появлением новых типов акторов, осуществляющих нормотворчество (как государственных, так и частных) и новых типов источников права. Это вынуждает нас обратиться к анализу концепций глобального управления, транснационального права и глобального административного права, которые сфокусированы на вышеупомянутых трансформациях в этой сфере. Таможенные органы сейчас переживают переход от традиционной миссии исключительно сборщиков налогов к субъектам, ответственным за широкий спектр задач, включая вопросы безопасности и защиты, содействия торговле, совместного управления границами и т.д. Все эти задачи должны выполняться на высоком уровне гармонизации, унификации и стандартизации с признанными международными нормами и правилами. Учитывая специфику новой миссии таможенных органов, основное внимание уделяется двум относительно новым их задачам: обеспечению безопасности и упрощению процедур торговли. Отмечены также основные современные инструменты для реализации таких задач: функционирование “единых окон” для международной торговли и применение принципов надлежащего управления к таможенным операциям.

Ключевые слова: торговая политика, таможенные правила, таможенные формальности, содействие торговле, безопасность, глобальная цепь поставок, "единое окно", надлежащее управление, ВТО, СТС, СЕФАКТ ООН. 